\title{
Strategies to Promote Regional Innovation
}

\author{
Andriele De Pra Carvalho, Paula Regina Zarelli \\ UTFPR, Francisco Beltrão, Brasil \\ Marco Antonio Harms Dias \\ UNIVALI, Itajaí, Brasil
}

\begin{abstract}
A favorable environment for the exchange of information and innovation is able to provide the economic and social progress. Thus, this article aims to propose a study methodology to develop strategies for promoting technological innovation, to answer the research question: What actions to leverage the innovative potential of a region? Data were collected through qualitative and quantitative approaches. The study was characterized as exploratory, descriptive, and inventory. The study sample was composed of the industrial spectrum of Francisco Beltrao region. Innovation indexes were identified companies operating in areas of greatest economic importance. Representatives of the companies were interviewed for the researcher could analyze their knowledge of the laws that encourage innovation and actions imposed by the interested parties and the municipal government. Interested parties were also interviewed to verify the effectiveness of actions. The main results indicated a low overall rate of innovation of companies in the Francisco Beltrao region. Another point was the very low number of companies they knew about laws and incentives. The higher content of knowledge of these laws and actions of stakeholders were among the companies participating in the single business hub of the city looking for technological innovation. The main conclusions brought proposed strategies to promote technological innovation.
\end{abstract}

Keywords: regional development, innovation management, sustainable development, innovation, sustainable, management

\section{Introduction}

Technological innovation has become an important subject in academic and business spaces. Managers note the significant importance of developing regional innovation potential to ensure competitiveness to businesses, providing a favorable environment to knowledge sharing, thus, generating innovations capable of leveraging economic and social progress.

Innovation means survival facing an increasingly fierce competition, means more sustainable businesses. Thus, to introduce an innovation propitious culture opens access to strategies that enable to manage this innovation within the organization, and the benefits of innovation go beyond company boundaries, benefiting society.

Andriele De Prá Carvalho, Ph.D., professor and researcher, University Federal Technological University of Paraná (UTFPR), Francisco Beltrão, Brazil.

Paula Regina Zarelli, Ph.D., professor and researcher, University Federal Technological University of Paraná (UTFPR), Francisco Beltrão, Brazil.

Marco Antonio Harms Dias, Ph.D., professor and researcher, University of the Itajaí Valley (Univali), Itajaí, Brazil.

Correspondence concerning this article should be addressed to Avenida General Osorio, 565, cango, CEP 85604-240, Francisco Beltrão, Paraná, Brasil. 
Innovative potential of a region is considered strategical to local sustainability. A region that has companies with potential to innovate, stands out in competitive market and generates benefits to the entire society. Before this, the present article aims to enhance technological development strategies to regional companies from a study in Francisco Beltrão region, through technological innovation indicators' analysis. In this context, the question arises: Which strategic actions can promote technological innovation in regional companies?

Thus, the objective of this article is to propose strategies to increase technological innovation's generation in regional companies from a model applied in Paraná’s southwest region of Brazil.

The study contributes in this way to knowledge production, enriching academic environment on issues involving cooperation and with information and updates in the coverage areas. The research's result will enable dissemination and adaptation of the methodology to other regions aiming at economic sustainability of local businesses by innovation bias.

Still, it is a challenge and opportunity to indicate ways so that economic and regional social sustainability occur.

\section{Literature Review}

\section{Technological Innovation as Competitive Advantage}

Technological innovation, focused as strategy to promote development in companies achieved growth in the nineties with Organization's Activities for Cooperation and Economic Development (OECD). Moreover, in Brazil, its performance was stronger from National Conference of Science, Technology, and Innovation, in 2001, and on state level, it was focused on Industrial, Technological, and Foreign Trade Policies (PITCE).

However, turning to micro-regional space, growth was obtained more slowly, with the aid of National Association of Entities Promoting Innovative Enterprises (ANPROTEC) and, in productive sector, growth was grounded by National Association for Research, Development, and Engineering of Innovative Companies (ANPEI) and National Industry Conference (CNI).

These initiatives to innovation's visualization as strategy were taken mainly after a presented low degree of Industry's Technological Innovation, according to data from Industry's Technological Innovation Survey (PINTEC), 2010.

In this context, organizations in the struggle to survival in globalized economies seek to find mechanisms to increase production and enable innovation, in addition to financial resources at a competitive cost. Companies are opening themselves and restructuring themselves to the new age. "The world in which the most important corporate decisions could be taken behind closed doors is disappearing” (Senge \& Carstedt, 2001, pp. 120-128).

Companies that seek to maintain their level of competitiveness in labor market need to constantly innovate, searching to expand their competitive advantage facing competitors. Thus, before the growing market competition, Innovation Management was correlated to other organizational concepts and, according to Plonski (2005), who constitutes the creation of a strategy.

Innovation does not occur in isolation, but depends on several factors in organizational context. One of these factors considered relevant is employees' support of a company, i.e., staffers actually committed and that can make Innovation Management happen (J. A. Fitzsimmons \& M. J. Fitzsimmons, 2004).

In order that innovation can indicate a safe path and bring viable strategies to the organization's success, skilled people are needed to ensure this dynamic's success. In this sense, Schumpeter (1988) understands 
innovative organization as the one that starts with an idea, and from efforts, it is transformed into a product, service, company, or technology. Innovations are measured by its contribution to market, to customer.

To implement innovation, the organization needs a favorable and expansive organizational environment for this to happen and be successful, i.e., innovation must be incorporated into company's business vision (J. A. Fitzsimmons \& M. J. Fitzsimmons, 2004).

Technological development is increasingly being driven by the market (Allarakhia \& Walsh, 2011) and, despite this presented context, there are contrasting views aimed at technological innovation. Because of an often erroneous' vision, wear and attractive capacity's evanescence are risks facing two major phenomena: one is government initiatives' discontinuation even before foreseeing their benefit; and the other is public investment's disregard.

The understanding of what technological innovation is (and is not) had been quoted by Freeman and Soete (1997) by stating that there are a variety of understandings about the Innovation term, which is often mistaken for invention, but innovation searches to make invention timely.

Plonski (2005, pp. 25-33) mentions three major conceptual errors: "reductionism (to consider innovation only the technology-based type), enchantment (to consider technological innovation only the spectacular one) and mischaracterization (to lose control of technological change's requirement of this innovation)".

It is important to review and consider these components to technological innovation, recalling Freemann and Soete's (1997) ideas, which state the distinction between innovation and invention. However, still many texts take patents (which are inventions) as a basis for measuring technological innovations. Nonetheless, these patents still have a long way to reach utilization's condition and become innovations. Based on patents, are also excluded as data to innovation, copyrights, or other means of intellectual property. Since, often, patents created here in Brazil are recorded by companies' arrays located abroad (Plonski, 2005).

Following the needs for a Movement favoring Innovation, quoted by Plonski (2005), it is presented the recognition of systemic and self-coordinated character of technological innovation, and the way to better assimilate is through human genius. In a more comprehensive understanding, innovation can be compared to a process, by starting to privilege attitudes, behaviors, and practices, such as a change's capacity, which improves creativity facing challenges.

As a process, it will not limit itself to a collection of facts, but a sustainability vital dynamics, considering its systemic and self-coordinated character more advanced if compared to innovation in the traditional way, which is cooperation among scientific and technological institutions and government. It is proposed a techno-economic network, involving public laboratories, research centers, industries, among others, that through intermediaries' circulation, such as documents or money, will give substance to nodes of the network (Plonski, 2005).

Regarding the final factor needed to create a favorable movement for technological innovation, Plonski (2005) reports the establishment of an adequate support, including a critical assessment of the rich national experience in public policies aimed at technological innovation. These policies generated within the government, based on financial stimulus, with tax incentives' establishment and productivity's grants; in moral stimulus, with recognitions; in stimulus-oriented to innovation in small businesses, educational mechanisms associated to purchasing power and technological infrastructure's availability.

To self-coordination, it needs to define which the country's project is and how technological innovation can guide it from tax exemption and public policies' competence appreciation, because technological 
development, in Brazil, comes from fragmented mechanisms, concentrating on virtuous processes, generating distortions.

It is necessary to establish something that goes beyond cooperation, but a dynamic coordination among those involved in innovation through a policy to technological innovation (Plonski, 2005).

\section{Regional Development}

Regional innovation can be set as the place where relations between social, economic, and cultural sectors occur, being these lived in constant changes and in an accelerated way. Therefore, Veiga (2006) points out the need for a participatory planning model to this development, as the region is at the center of strategies that aim at competitiveness and economic attractiveness, and it can be generated with popular participation, anchored local institutions, and society's leaders.

Regional development mean points that lead to a planning's application in order to make it sustainable (Veiga, 2006), and a sustainable regional planning requires a degree of technological training of the involved agents, and innovation factor considered as one of the main factors that differ regions' developments.

Innovative capacity is influenced by regional factors, turned up this analysis interesting. Rock and Dufloth (2009) report that regional differences in innovation activity levels can be substantial, and to identify the main characteristics and factors that promote innovation activity and specific sectors' development at regional level, can help innovation processes' understanding and be valid to policy making. In this sense, we can verify the need to look for data that measure innovation in Francisco Beltrão region, because there is no research or data collected to date.

\section{Research Methods}

\section{Research Type}

The study is characterized as exploratory because it intends to meet and explore regional reality. It also takes the form of descriptive research by enabling surveyed population characteristics' description (Oliveira, 2004), and stocktaking research to generate knowledge for practical application and search for solutions to specific problems, involving local interest (Mattar, 1996).

The approach is qualitative because of the analysis, interpretation and opinions understanding, and data gathered in a broader context, in addition to statistics' demarcations (Miguel, 2010).

\section{Population and Sample}

Sampling frame is composed by companies of Francisco Beltrão/PR region, by municipal government and organs that act as stakeholders.

About companies, sampling was defined by statistical average, with $95 \%$ confidence level of companies operating in areas of greatest economic importance to the region. This was made because of the understanding that these companies are potentially innovative, because economic relevance is one of the companies' variables that participated in the sampling selected by Pintec's research (2010), and considering that companies that include these activities are the ones participating of Regional Development Programs, in line with Brazil Innovative research from FINEP. The areas of greatest economic importance to the region are consumer products, food processing, metal-mechanic and plastic, and information technology.

Industry and Trade Secretary and Planning Department represent municipal government.

Stakeholders are represented by Paraná Federal Technological University (UTFPR), Paranaense 
University (Unipar), Southwest Paraná Union Education (UNISEP), Beltronense Center for Technologic Information (NUBETEC), Development Agency, Innovative and technological projects' incubator (FindEx), Regional Innovation System (RIS), Micro and Small Business Support Service (Sebrae), Paraná Industries Federation (FIEP), Paraná Southwest Commercial Associations' Coordination (CACISPAR) and Commercial and Business Association of Francisco Beltrão (ACEFB).

\section{Tools and Data Collection}

In the course of this research, there were developed the following steps:

(1) Primary data collection with the government;

(2) Questionnaire application to companies' managers to analyze innovation degree, adapted from Reis (2010). Integer number 1 , comprising 0.5 of efforts' indices and 0.5 of results' indices, represents maximum innovation degree.

(3) Using standard deviation calculation and confidence interval, there were carried out interviews in companies that were above and below this limit. Eight interviewed companies presented innovation degree above standard deviation range and five companies disclosed innovation degree below standard deviation range, aiming to analyze their access to actions for innovation, and which are the possible actions they consider important to leverage their innovative potential.

(4) Third stage comprised interviews applied to municipal authorities and stakeholders, seeking information about innovative policies and actions.

(5) Data were analyzed from content's perspective that applies to written texts or any communication's analysis.

\section{Research Results}

They represent the research's results based on the study's objectives and the methodology presented.

\section{Stakeholders Interviews’ Analysis}

The goal through interviews was to raise the existing actions and proposals by stakeholders to encourage innovation in Francisco Beltrão region. The involved stakeholders, as well as the reported answers, follow below:

Based on interviews with stakeholders, it is possible to note that all of them have an interest in partnerships with the government to leverage companies' innovative potential in the region.

Part of these stakeholders, namely: ACEFB, NUBETEC, FindEx, RIS and Development Agency mention funds' transfer and support to assist companies. However, apart from the existing core, which is of technology information, the other stakeholders have reported small share of region's entrepreneurs in partnerships.

Stakeholders implemented all actions and seminars, but technology information's companies, participating of NUBETEC, composed the majority's participation, because this branch represents a form of continuous training and information source.

Through this point, it is noted why there are only Information Technology's area companies in Findex incubator. Nevertheless, this also is limited and does not have full performance as designated for an incubator.

ACEFB is also a way to contact companies and a vehicle to projects' dissemination and implementation, such as UTFinova, but also with low participation numbers, comprising only $11 \%$ of its members. The other companies only seek to join the association because of partnership with Credit Protection System Program (SPC) consultation. 
Another interesting point is with respect to universities, which have expressed interest in helping this leverage innovation's process in the region and state that, today, their aid often is limited to loan physical structure to some courses, not to knowledge transfer.

In an interview with the head of SEBRAE, he also highlighted the importance of gathered actions with educational institutions, which are knowledge's sources. He yet focused on the implementation of a project developed by SEBRAE aimed at implementing innovation in Francisco Beltrão.

As expounded by the respondent, the project is ready to implementation and is of municipal government interest. The project follows SEBRAE methodology and searches legal aspects, public policy and credit lines, technology network with forums, maintenance of existing assets, creating a technology transfer center, promoting a culture for innovation and integrate researches between university and company. One detail that must be highlighted is that the project is generic and not directly applied to Francisco Beltrão's reality, through previously developed studies focusing all involved with innovation.

FIEP is another partnership that has action's mechanisms to help innovation leverage, but only operates in industries. FIEP's actions have potential to boost innovation.

UTFPR also raised emphasis to the need for mechanisms to better publicize, educate and form a favorable innovation culture, highlighting even the teachers' role, who should encourage more entrepreneurship and not only student's academic training. This would help innovative ideas' creation and generation.

\section{Analysis of the Results of Regional Government Representatives’ Interviews}

Analysis of the interviews applied to government sought, through Trade and Industry Secretary and Planning Department, to focus on actions they have pursued to increase Francisco Beltrão/PR region's innovative potential, as well as presented results and new actions' projects.

Thus, it was noted that few actions were created or implemented. A survey to analyze region's prominent areas and the necessary infrastructure was started, but were not taken measures to enhance its development. Municipal government demonstrates to know the importance of innovation incentives, particularly by recognizing incubators and technologic parks' importance, but expects that stakeholders initiate the necessary procedures.

\section{Companies' Analysis}

Companies' analysis was composed of two phases, the first one with questionnaire's application as instrument proposed by Reis (2010), and the second stage through an interview with companies with higher and lower innovation levels, as statistical calculation standard deviation range.

\section{Questionnaires’ Analysis}

The following tables present innovation rates of companies' samples divided by economic activity area. Each table acronym represents the research's area: HRI—Human resources dedicated to R\&D\&I; IPD—Financial Investment in R\&D\&I; TIR-Investment Type Held; IOC-Organizational Configuration Favorable to Innovation; EFI—Physical Structure of the Company allocated to R\&D\&I; CUL—Organizational Culture Focused on Innovation; PGT - Technology and Innovation Management Practices; GMI-Maturity Degree in innovation processes; NPI-Innovation Projects' Number; VTT—Sale of Technology to Third Parties; PAT—Number of patent applications in the last three years; PRE—Awards' number received by the company; IE—Efforts' Index for Innovation; IRI—Results' Index of Results; IEI—Innovation Index of the Company.

In Table 1, it is possible to observe innovation index's average of 61 companies belonging to consumption's economic activity that responded to the questionnaire. 
Table 1

Innovation Index of Consumer Products’ Activity Companies

\begin{tabular}{lllllllllllllll}
\hline Company & \multicolumn{11}{c}{ Indicators } \\
\hline & IRH & IPD & TIR & COI & EFI & CUL & GMI & PGT & NPI & PFI & EIP & VTT & PAT & PRE \\
\hline $\begin{array}{l}\text { Each indicator } \\
\text { average }\end{array}$ & 0.14 & 0.11 & 0.2 & 0.6 & 0.17 & 0.4 & 0.38 & 0.33 & 0.2 & 0.2 & 0.2 & 0 & 0 & 0 \\
Higher index & 0.47 & 1 & 0.6 & 1 & 1 & 0.8 & 0.87 & 0.96 & 1 & 1 & 1 & 1 & 1 & 1 \\
\hline
\end{tabular}

Source: Own elaboration.

These companies in the general table showed the lowest innovation rate, only industrial companies ranked above overall average. Efforts' indices to innovation, although low, were higher than results' indices, representing that although companies focus on strategies to innovation, there is not a direct result.

Another interesting point is the low financial investment in research and development. This question, combined with low levels, proved that companies are not geared to innovation. Weber and Hemmelskamp (2005) highlight the importance of investment and resources to generate innovation process.

In Table 2 are displayed innovation rates of six companies belonging to economic activity of agri-food sector that responded to the questionnaire.

Table 2

Innovation Index of Agri-Food Companies

\begin{tabular}{llllllllllllllll}
\hline Company & \multicolumn{11}{c}{ Indicators } \\
\hline & IRH & IPD & TIR & COI & EFI & CUL & GMI & PGT & NPI & PFI & EIP & VTT & PAT & PRE \\
\hline $\begin{array}{l}\text { Each indicator } \\
\text { average }\end{array}$ & 0.01 & 0.03 & 0.03 & 0.04 & 0.02 & 0.04 & 0.03 & 0.04 & 0.03 & 0.03 & 0.03 & 0.01 & 0.01 & 0.01 \\
Higher index & 0.4 & 0.6 & 0.9 & 1 & 1 & 0.79 & 0.76 & 0.89 & 1 & 0.8 & 0.6 & 1 & 0.4 & 0.8 \\
\hline
\end{tabular}

Source: Own elaboration.

These companies also reported low innovation rates in most cases, however, the overall innovation index is greater than the related to consumer products' companies and, again, the greatest innovation index present is the one constant of industries' research.

In this context, Pintec research (2010) and Oslo Manual (2005) focus on the importance of industrial enterprises as the largest innovation's boosters.

Continuing innovation indices, Table 3 features 14 companies in metal-mechanic industry and plastic that answered the questionnaire.

Table 3

Innovation Index of Metal-Mechanic and Plastic Companies

\begin{tabular}{lllllllllllllll}
\hline Company & \multicolumn{11}{c}{ Indicators } \\
\hline & IRH & IPD & TIR & COI & EFI & CUL & GMI & PGT & NPI & PFI & EIP & VTT & PAT & PRE \\
\hline $\begin{array}{l}\text { Each indicator } \\
\text { average }\end{array}$ & 0.03 & 0.03 & 0.04 & 0.09 & 0.02 & 0.07 & 0.07 & 0.06 & 0.04 & 0.04 & 0.03 & 0 & 0 & 0 \\
Higher index & 0.42 & 0.4 & 0.55 & 0.7 & 0.6 & 0.65 & 0.66 & 0.76 & 0.4 & 0.4 & 0.6 & 0 & 0 & 0 \\
\hline
\end{tabular}

Source: Authors.

In this segment, companies were all within the range defined as standard through standard deviation calculation.

Finalizing innovation indexes, one can visualize in Table 4, 13 companies in Information Technology 
sector that responded to the questionnaire.

Table 4

Innovation Index of Information Technology Companies

\begin{tabular}{lllllllllllllll}
\hline Company & \multicolumn{11}{c}{ Indicators } \\
\hline & IRH & IPD & TIR & COI & EFI & CUL & GMI & PGT & NPI & PFI & EIP & VTT & PAT & PRE \\
\hline $\begin{array}{l}\text { Each indicator } \\
\text { average }\end{array}$ & 0.06 & 0.06 & 0.05 & 0.09 & 0.13 & 0.08 & 0.07 & 0.07 & 0.06 & 0.06 & 0.04 & 0.03 & 0 & 0.01 \\
Higher index & 0.56 & 1 & 0.8 & 1 & 0.7 & 0.72 & 0.79 & 0.72 & 0.8 & 0.8 & 0.6 & 1 & 1 & 1 \\
\hline
\end{tabular}

Source: Own elaboration.

Information technology was the sector that presented the highest percentage of companies with innovation rate above the overall average. These companies are also those with support from municipal government through Francisco Beltrão Information Technology Center (NUBETEC) and, that through this core can follow the main carried out actions, in addition to seeking knowledge through lectures and visits that is innovation's basis, according to Plonski (2005).

Overall, it is possible to observe that companies from all business areas have a low level of human resources (RHI) dedicated to research and development in company, not pointing internal staff valorization with academic training.

Organizational learning is the power base for the company to adapt necessary changes to remain competitive. Moreover, investing in research and development is a way of searching for innovation (Reis, 2008). In the same way, Arruda, Rossi, and Savaget (2009) state that a company should not let lack of financial resources affect innovation's generation.

However, it was observed in the researches that financial investment in Research and Development (IPD) is very low, which concurs with some stakeholders' statements that companies have no interest in innovation and are accommodated with their current products.

Effected Investments (TIR), which range from equipment purchasing, innovation training employees to new technologies' development, can also be considered low, as well as physical structure intended to innovation's research and development, which only showed significant value in industry, and in other companies were not even computed.

As for favorable organizational configuration to innovation (IOC), mostly reached high levels and encouraging innovation. Often because when the company is medium or small, it facilitated management's decision-making power, which is considered index's maximum level. In this regard, Gallagher (2003) stresses the importance of the leadership influencing employees to decision-making.

When the researched subject was organizational culture to innovation (CUL), it was noted that indicators, in most cases, were low, being raised only in industries that already have an innovative culture. This factor proves how organizational culture is not conducive to innovation, confirming data from interviews with involved stakeholders. According to Gallagher (2003), organizational culture dictates the philosophy imposed by the company.

Maturity Degree in Innovation Processes (GMI) was one of the indicators that exhibited higher levels, together with Technology and Innovation Management Practice (PGT), demonstrating that the company's administrator has necessary knowledge to invest in innovation because, according to Barbieri, Alvarez and Cajazeira (2009), innovation and organizational success is a set of administrator's interaction with 
organizational environment.

By questioning the companies on index's number of projects that generated innovation (NPI), most were limited to only one project in the past three years, and many to any project, which repots the low score in innovation.

Other indexes that represent innovation's result and were also low are: Arising Billing Percentage of New Projects (PFI), Arising Economy Percent Improvement in Process (EIP).

When asked about index technologies' sales (VTT), again most companies responded negatively, with few that supply this factor, i.e., those that have sold technology. Technology's sale, as well as applied patents number's index (PAT) concentrates limited to surveyed industries. These indices are restricted to creating products and completely new processes, which, according to Oslo Manual (2008), are called radical innovation.

Another factor limited to industry, and still with low level was PRE, Awards Received Number.

Table 5 shows overall average's innovation rates of the companies surveyed in Francisco Beltrão city and proves that they are on average far below the ideal defined by Reis' research tool (2010).

Table 5

Innovation Indexes Overall Average

\begin{tabular}{|l|l|}
\hline IEI Medium $=$ & 0.36 \\
\hline IRI Medium $=$ & 0.25 \\
\hline IEI Ideal $=$ & 0.918 \\
\hline IRI Ideal $=$ & 0.97 \\
\hline IIE Medium $=$ & 0.33 \\
\hline IIE Ideal $=$ & 0.944 \\
\hline
\end{tabular}

Source: Authors.

Based on Table 5, average innovation index of companies was 0.33 , well below the considered ideal that is 0.94, demonstrating a great deficiency of companies in Francisco Beltrão region to innovate.

This innovation index can be divided between efforts and results' levels. The average effort index to companies' innovation in Francisco Beltrão city reached 0.36, while the ideal would be 0.92 . The average outcome rate was 0.25 , while the ideal would be 0.97 .

These data clearly demonstrate that companies are more struggling to innovation than getting results.

\section{Analysis or Discussion}

After the questionnaires, based on innovation indexes' results, companies were interviewed below and above the lower limit of standard range.

To calculate standard range, first, standard deviation was defined considering a 95\% confidence level. Thus, standard deviation of innovation index was set at 0.26 .

After discovering standard deviation of innovation index, this was used to calculate standard confidence interval, which was established with a lower limit of 0.21 to the upper limit of 0.30 .

In other words, companies that did not fit in standard range set, remaining above the upper limit set as default average among companies or below this limit set as default, were chosen for interview.

Companies selected for interview, framed below the limit set as default, which is 0.21 , i.e., with lower innovation rate. Companies selected for interview framed above the limit set as the default, which is 0.30 , i.e., 
companies with higher innovation rate.

None of these companies claimed to have knowledge of the laws that encourage innovation, in addition to not being part of any core or having contact with agencies that support innovation.

These companies state to have not sought such agencies or support believing that there are no projects, laws, or improvements directed by the government or stakeholders within reach.

These companies' managers, with lower innovation degree, also described that they believe that innovation is a very distant reality, something complex and difficult to put into practice, demonstrating lack of knowledge on technological innovation management.

This lack of knowledge about innovation management's importance largely happens due to lack of an innovative culture that is combined with management practices transmitted by the administrator (Gallagher, 2003).

When asked about what municipal government or partner organizations could do to leverage a company's innovative potential, they did not know what to answer. Only two of the respondents commented that they could develop courses or lectures to knowledge's education and dissemination, and two others responded that municipal government should reduce taxes so entrepreneurs could invest more in companies.

At this point, it is possible to note how the existing actions by municipal government and some stakeholders do not reach companies' range, and that these companies do not even know about such actions.

Based on companies with higher innovation degree, it is possible to analyze, except for companies from Information Technology area, participants of NUBETEC and ACEFB, that other companies do not credit to municipal government any merit related to their innovations.

This was realized in the course of interviews, especially with regard to the fifth question: "In your opinion, as a manager, what do municipal government and partner organizations can do to leverage innovation within your company?” Managers failed to visualize actions in which municipal government could contribute.

Companies' participants of innovation entities' partners, quoted as stakeholders, were those who answered affirmatively about knowledge of the laws that encourage innovation. On the other hand, all companies that do not participate of any partner organization demonstrated lack of knowledge regarding these laws.

Among the companies that know the laws that encourage innovation, it became clear that none of them has knowledge about local laws, and only one company's representative interviewed commented about knowing one of state's laws. That demonstrates, thus, the lack of disclosure and access of companies to these laws.

An interesting point to be raised is that, even without high knowledge of the laws to encourage innovation or participation in any core or partnership with stakeholders, many of these companies achieved a high degree of innovation compared to others. That is, if actually implemented a greater support and an innovative culture, each of the companies' potential could be leveraged.

The lack of an innovation-oriented culture also limits companies' actions in the region, it is noted that there is a reluctance to innovate and a lack of focus on its real benefits.

The creation and patent registration of new products got low rates, and the interviewed companies have shown no interest in creating new products or processes for fear of investing financially and, then, be copied. This fear, presented by respondents, features a lack of knowledge of Innovation Management and lack of access to technology.

During the research, it is possible to note that the region's public government and the involved stakeholders are opened to actions that assist in promoting innovation. Thus, based on survey data there were prepared the 
following actions to leverage innovative potential, according to Table 6 .

Table 6

Performance Strategy

PERFORMANCE STRATEGY

Structuring or supporting axes: education, sustainability, society's participation and technology.

Strategic vector: municipal government to create a professional composite committee to act as intermediaries and strategies' executors.

\begin{tabular}{|c|c|c|}
\hline Searching area & Strategies & Expected action \\
\hline 范 & $\begin{array}{l}\text { - Create new credit lines and income generation; } \\
\text { - Public support policy; } \\
\text { - Create legislation to operate a hub of innovation } \\
\text { and technology; incubator, technology park, and } \\
\text { intellectual property registration. }\end{array}$ & $\begin{array}{l}\text { - Through these facilities creation and resources, it is } \\
\text { intended to attract innovative companies; } \\
\text { - Public policies are strategic to monitor actions' course } \\
\text { and progress to innovation, educating businesses about } \\
\text { the advantages; } \\
\text { - The legislation will act as legal support to developed } \\
\text { actions. }\end{array}$ \\
\hline Operation area & Strategies & Expected action \\
\hline 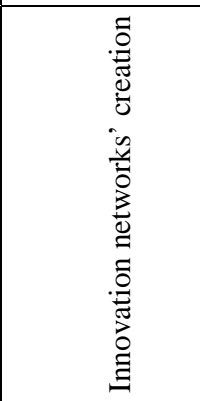 & $\begin{array}{l}\text { - Create centers to work in all branches of the } \\
\text { greatest potential activities to the city; } \\
\text { - Expand support and courses to HR expertise; } \\
\text { - Create a technology transfer center; } \\
\text { - Create qualified commission to follow up the } \\
\text { projects; } \\
\text { - Develop partnerships with stakeholders to meetings } \\
\text { and innovation projects; } \\
\text { - Provide physical structure to projects’ execution; } \\
\text { - Provide instruction on the appropriate technology } \\
\text { to each area. }\end{array}$ & $\begin{array}{l}\text { - With centers' creation it is intended to make major } \\
\text { participation of companies in public policy or other } \\
\text { actions aimed at innovation, better dissemination of } \\
\text { projects developed in cities and partnerships with } \\
\text { stakeholders; } \\
\text { - With the help of a committee and physical structure for } \\
\text { development projects, it is expected significant increase } \\
\text { of new proposals and monitoring of them. }\end{array}$ \\
\hline 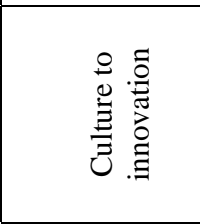 & $\begin{array}{l}\text { - Promote, in partnership with stakeholders and } \\
\text { cores, seminars, meetings, forums, debates and } \\
\text { courses; } \\
\text { - Present idea generation programs. } \\
\text { - Implement projects submitted by stakeholders (e.g. } \\
\text { UTFinova, SEBRAE, and FIEP). }\end{array}$ & $\begin{array}{l}\text { - Through these actions it is intended to disseminate } \\
\text { knowledge on technological innovation management } \\
\text { and its importance to the company; } \\
\text { - It aims also to disseminate a culture of innovation; } \\
\text { - Commitment to Innovation Management. }\end{array}$ \\
\hline 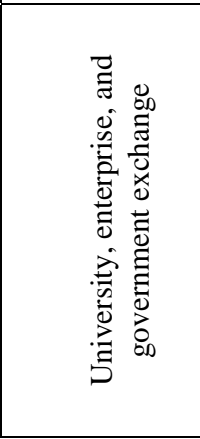 & $\begin{array}{l}\text { - Leverage the technology hotel; } \\
\text { - Create the Technology Park; } \\
\text { - Implement joint research between universities x } \\
\text { companies; } \\
\text { - Boost the technological incubator; } \\
\text { - Strengthen mechanisms that contribute to ideas’ } \\
\text { generation; } \\
\text { - Perform debates in partnership with companies and } \\
\text { universities; } \\
\text { - Bringing businesses to the university to create } \\
\text { partnerships in ideas and innovative products’ } \\
\text { acquisition. }\end{array}$ & $\begin{array}{l}\text { - It is intended to be established partnership among } \\
\text { company, government, and university, in order to } \\
\text { structure and leverage incubators and technology parks’ } \\
\text { progress; } \\
\text { - It is expected a large number of innovative projects } \\
\text { incubated; } \\
\text { - Greater participation of companies in academics } \\
\text { through debates and partnerships on projects. }\end{array}$ \\
\hline
\end{tabular}

Source: Own authors.

\section{Conclusions}

Innovation Management is key to a region's development, which contributes to advancement, development, and local sustainability. However, this innovation must be managed for it to happen. This research brought a research application methodology to potential and innovative analysis and subsequent actions stocktaking. Among the results, it is possible to analyze that:

Partnership among university, business, government, and stakeholders is the way to achieve innovative potential leverage because each of these entities individually does not cover companies' needed amount, 
especially with regard to an innovative culture implementation. Municipal government should rather create strategies to maximize innovation in the region, getting this partnership.

Research demonstrates that there is a lack of companies' participation in many of innovation's programs and incentives provided by stakeholders. Regional Innovation System itself is very little demanded and often only by Information Technology companies. One of the strategies is the search to implement companies' interest centers, and through them, provide and present programs and strategies created by municipal government.

The implementation of exchange among universities, business, and government, in the scope of their own structures, to maintain and filter ideas, such as technological hotel, incubators and technology park, is a way of disseminating innovative culture and generating skilled labor.

Partnership between stakeholders is essential to make successful an innovative culture implementation in Francisco Beltrão in order to assist in achieving the defined strategies. They are at legal environment level, through creation, specific laws' maintenance and strengthening, support policies and income generation, innovation networks' development to organize centers to each activity area, skilled labor training, commission for projects' monitoring and wide-ranging physical structure.

Another point is the creation of a conducive innovation culture, and diffusion of interesting technologies to each area through seminars, in addition to promoting exchanges among universities, businesses, and government, leveraging technology assets.

From these strategies, municipal government can implement a favorable environment to technological innovations’ generation in Francisco Beltrão city.

\section{References}

Allarakhia, M., \& Walsh, S. (2011). Managing knowledge assets under conditions of radical change: The case of the pharmaceutical industry. Technovation, 31(2-3), 105-117.

Arruda, C., Rossi, A., Savaget, P. (2009). Oportunidades e desafios de inovar. Revista da Fundação Dom Cabral, 2(8), 37-43. Barbieri, J. C., Álvares, A. C. T., \& Cajazeira, J. E. R. (2009). Gestão de ideias para inovação contínua. Porto Alegre: Bookman. Brasil Inovador. (2006). O desafio empreendedor: 40 histórias de sucesso de empresas que investem em inovação. Brasília: IEL.

Fitzsimmons, J. A., \& Fitzsimmons, M. J. (2004). Administração de serviços: operações, estratégia e tecnologia da informação (4th ed.). Porto Alegre: Bookman.

Freeman, C., \& Soete, L. (1997). The economist of industrial innovation (3rd ed.). London: Pinter Publishers.

Gallagher, R. S. (2003). Os segredos da Cultura Empresarial: Como entender a alma das culturas Organizacionais bem sucedidas. Rio de Janeiro: Campus.

Mattar, F. N. (1996). Pesquisa de marketing: edição compacta (5th ed.). São Paulo: Atlas.

Miguel, P. A. C. (2010). Metodologia de pesquisa em Engenharia de Produção e Gestão de Operações (2nd ed.). Rio de Janeiro: Elsevier.

Organização para a Cooperação e Desenvolvimento Econômico-Manual de Oslo: Diretrizes para coleta e interpretação de dados sobre inovação. (2005). Disponível em <http://www.mct.gov.br/upd_blob/0011/11696.pdf>. Acesso em: 15 abr. 2011.

Oliveira, S. L. (2004). Tratado de Metodologia Científica. São Paulo: Pioneira Thomson Learning.

Pintec. (2008). Pesquisa industrial de inovação tecnológica. Disponível em: < http://www.ibge.gov.br/home/estatistica/economia/industria/pintec/2008/default.shtm>. Acesso em: 20 nov. 2012.

Plonski, G. A. (2005). Bases para um movimento pela inovação tecnológica no Brasil. São Paulo Perspec, São Paulo, 19(1), 25-33.

Reis, D. R. (2010). Gerenciar a Inovação: Um Desafio para as Empresas. Curitiba: IEL/PR.

Reis, D. R. (2008). Gestão da inovação tecnológica (2nd ed.). São Paulo: Manole.

Rocha, E. M. P., \& Dufloth, S. C. (2009). Análise comparativa Regional de indicadores de Inovação Tecnológica Empresarial: 
Contribuição a partir dos dados da Pesquisa Industrial de Inovação Tecnológica. Revista Perspectiva em Ciência da Informação, 14(1), 192-208.

Senge, P. M., \& Carsedt, G. Rumo à próxima revolução. (2001). Revista HSM Management, São Paulo, 5(27), 120-128.

Schumpeter, J. (1988). A teoria do desenvolvimento econômico. São Paulo: Nova Cultural.

Vasconcelos, M. A., \& Barbieri, J C. (Org.). (2004). Organizações inovadoras: estudos e casos brasileiros. (2nd ed.). Rio de Janeiro: FGV.

Veiga, J. E. (2006). Territórios para um desenvolvimento sustentável. Territórios, Ciência \& Cultura. São Paulo.

Weber, M., Hemmelskamp, J. (2005). Towards enviromental innovation system (1st ed.). Austria: Springer. 